\title{
ON THE PATHOLOGICAL VALUE OF THE GASSERIAN, LENTICULAR, SPINAL AND CARDIAC GANGLIA.
}

\section{BY W. HALE WHITE, M.D. \\ Phyeician to Guy's Hoppital.}

Is the Medico-Chirurgical Transactions, vol. Ixviii., I gave an account of an examination of a large number of superior cervical and semilunar ganglia, taken from persons dying of various disenses. These genglia were shown to vary more in size and shape, in different individuals, than any other organ in the body, and these variations were quite irrespective of the age, sex, station of life, or manner of death of the individual. Microscopical examination showed that the number of nerve-cells present in these ganglia was most variable, also that while a few cells had well marked nerve processes and an evident nucleus, very often the nerve-cell was nothing more than a minute mass of bright yellowish red granular pigment. Between these two extremes there were many intermediate forms, but almost all the nervecells deviated more or less widely from the typical nervecell with a well defined nucleus. The amount of connective tissue was very different in different specimens. For many years past I have been on the outlook for instances in which there was some evidence of pathological change in the ganglia, but except in two patients in whom abdominal malignant growth had invaded the semilnnar ganglia, I have not been able to find any which have been affected by pathological conditions.

These results pointed so strongly to the fact that the superior cervical and semilunar ganglia are in adult man functionless organs, that I examined the superior cervical ganglia of a number of mammals other than man, and also 
those of a number of human fotuses. The results were published in the Journal of Physiology, vol. viii., No. 2, and $I$ arrived at the following conclusions:-firstly, that human adult superior cervical ganglia vary as much in size as do those of the largest and smallest of other mammals, and that the size of the ganglion in other mammals varies directly as the size of the animal. Secondly, that haman superior cervical ganglia exhibit granular pigmented atrophic cells much more frequently than those of other mammals; that this condition, though present to some degree in monkeys,. diminishes regularly as we descend in the maminalian scale, till at last it is not seen. Thirdly, that human foetal superior cervical ganglia do not show any of these changes in their nerve-cells. These facts seemed to me to demonstrate that the superior cervical ganglion is becoming less and less important functionally, the higher we ascend in the animal scale, till in the human adult its minimum of importance is resched. It is, in fact, an atrophied degenerate organ like the coccyx or the appendix caeci.

In The Joumal of Physiology, vol. x., No. 5, I showed that the pigmented, granular, atrophic, degenerate appearance of the cells could not by any possibility be due to the method of preparation. I also prepared a series of superior cervical ganglia and arranged the descriptions of them according to the age of the patient, and found that of fortynine adults examined only one showed entirely normal nervecells, and of five children exsmined, all showed entirely normal nerve-cells. I also prepared additional sections of a large number of superior cervical ganglia from animals lower than man, and found that the cells were of the normal type in all save one ape. Preparations were made of a series of semilunar ganglia both from man and the lower mammals. The results agreed so completely with those obtained from an examination of the superior cervical ganglion, that I thought we might conclude that in lower mammals and young human beings the collateral ganglia (if we may judge from the superior cervical and semilunar) are functionally active, but that in monkeys there are evidences of the commencing loss of their function, which 
has completely disappeared in the human adult. Sections of the chief nerves. attached to the superior cervical and semilanar ganglia showed that they were, both in man and the lower mammals, structurally quite similar to ordinary heslthy nerves, and therefore we may conclude that they are functionally active.

The thoracic ganglia, which may be taken as the chief lateral ganglia, were examined in twenty-four persons, and the results were arranged according to the ages of the patients. They proved that the granular atrophic pigmented condition of cell was never so marked as in the collateral ganglia, but some of the cells from elderly persons showed it, while those from children and young adults were free from it. From this the conclusion. was drawn that in man the function of the lateral ganglia is maintained well into adult life and only begins to disappear in old age.

Lastly, in the Guy's Hospital Reports, vol. xlvi., the attempt was made to see whether these results were confirmed by human pathology, and it was found that they were, for it was shown that when the sympathetic ganglia were destroyed by extensive lesions, such as invasion by growth, no symptoms were produced which could be ascribed to the destruction of the ganglia, and also that in the case of all diseases which have been ascribed in intrinsic lesions of the ganglia, such a pathological explanation will not bear critical examination. Also many instances were brought forward from pathology to show that in man sympathetic nerves possess the same functions as in the lower animals.

Having thus proved that changes in the nerve-cells of the semilunar and superior cervical ganglia in human adults and in the thoracic ganglia in elderly persons are of no pathological importance, I thought it would be advantageous to examine the Gasserian and lenticular ganglia as the most accessible cranial ganglia, the spinal ganglia and the cardiac ganglia. The results of these examinations are given below:-

Gasserzan Ganglia.-Thirty-six of these were examined. They were taken from persons dying of various diseases. 
Some were males, some were females, some were old and some were young. In all cases the nerve-cells were well formed, of the rounded type of nerve-cell, without branching processes. There was a distinct nucleus and a distinct nucleolus. The border of the cell, which took the logwood stain well, was sharp. The capsules, which were well nucleated, were almost entirely filled by the nerve-cells. In many sections one, or perhaps two, nerve-cells showed some granular pigment, but they were never atrophic, and there was never anything like the extreme granular pigmentary atrophic change so often seen in the superior cervical and semilunar ganglia. The nerve fibres were all healthy. The ganglion had a fibrous capsule which sent in fibrous septa. The vessels appeared normal. As has been observed to be the case in the superior cervical and semilunar ganglia, the sections were often crowded with leucocytes. I do not know what significance is to be attached to this condition. In some ganglia a minute capillary hæmorrhage could be seen in the sheath of the ganglion. That it occarred shortly before death was clear from the fact that the blood colouring matter was not absorbed. These hæmorrhages are probably of no pathological value, for it is well known that minute intracranial hæmorrhages are very liable to take place shortly before death. Judging from the condition of the nerve-cells, there can be no doubt that in adult man the Gasserian ganglion is functionally active, and therefore any changes in its cells that may in the future be described, will be of pathological vahue. Ross (Diseases of the Nervous System, vol. i. Sec. edit., pp. 496 and 509) gives references to cases which show that aneurism of the internal carotid has been known to cause intractable neuralgia by pressure on the Gasserian ganglion, and in another patient an exostosis from the petrous portion of the temporal bone produced the same effect in a similar manner. Also Wyss and Kaposi have found neuritis of the Gasserian ganglion in cases of trigeminal herpes. In all these instances, however, there is no reason to doubt but that the pain and the eruption were due to inflammation of the nerve fibres in the ganglion and not to implication of the cells, for both these symptoms may follow an ordinary neuritis. 
Lenticular Ganglion.-I dissected out from the orbit several lenticular ganglia from the same patients whose Gasserian ganglia I have described, and Mr. E. H. Starling kindly cut ribbons of sections of them for me. These showed that the nerve-cells, although small, are perfectly healthy, each with a distinct nucleus. Many have short processes, sthers are of the rounded type. The cells fill their capsules. The nerve fibres, both white and grey, are healthy, and there is nothing noteworthy about either the fibrous tissue or the vessels. Changes, therefore, in the cells of this ganglion would be of great significance, and we may conclude that in man it is functionally active.

Spinal Ganglia.-I prepared sections from a number of ganglis from the posterior roots of the spinal nerves, taking some from the lumbar and others from the upper cervical region. So many text-books contain histological descriptions of this ganglion, that all I need do is to point out that many granular highly pigmented nerve-cells are to be found, but they are never so extremely atrophic as are those of the superior cervical and semilunar ganglia. The greater number of the cells are, however, very good examples of healthy-looking rounded nerve-cells which stain well with logwood and have a distinct nucleus. Pigmented cells are more common in the lumbar ganglia than in the cervical ganglia. Unless, therefore, the changes in the cells are very gross, it will be necessary, as there is not the same amount of pigmentation of cells in all the ganglia, to contrast a specimen supposed to be disessed with sections of precisely the same ganglion from other persons, before pronouncing its cells to be diseased. Baerensprung long ago described neuritis of these ganglia in a case of herpes zoster, but this was probably only a part of the neuritis of the roots of the spinal nerves which causes this affection. At present we do not know of any pathological affections of the cells of the spinal ganglia, most of which are probably functionally active, these ganglia having only recently begun to become degenerate organs.

Cardiac Ganglion Cells.-I cut sections of the wall of the left auricle, near the entrance of the pulmonary veins. 
Specimens taken from many patients were prepared, but often the sections did not happen to include any nerve-cells, but they were found in the following cases: a female, aged 73, who died from a strangulated femoral hernia, she had granular kidneys ; a female, aged 47 , who died from an aortic aneurysm; a female, aged 11 years, who died from exhaustion following bip disease; a male, aged 34 , who suffered from a dilated and hypertrophied heart, together with bad kidneys; a male, aged 8 years, who had mitral and aortic disease, together with an adherent pericardium; a male, aged 56, who died from the effects of a cerebral tumour; a female, aged 48, who suffered from atheroma, cerebral hæmorrhage, and mitral and tricuspid stenosis; a male, aged 64, who had chronic Bright's disease; a msle, aged 58, who died from general tuberculosis; and a patient whose canse of death was not stated. The nerve-cells were always considerably smaller than the cells of the larger ganglia in the body, but they appeared to be perfectly healthy cells without any pigmentation or granular change.

The conclusion, therefore, to which I am led is, that the cells of the semilunar and superior cervical ganglia of human adults are degenerate and functionless, and changes in them are of no pathological value, but such changes in the thoracic ganglia and the spinal ganglia, which are only partially degenerate and are probably in parts functionally active, may be of some importance; but the cells of the lenticular, Gasserian and cardiac ganglia are in human beings healthy looking and apparently functionally active, so that we may expect that any alterations in them will turn out to be of great pathological interest.

In the central nervous system groups of small strongly pigmented cells are often seen, as for example in the substantia nigra, substantia ferruginea, and smaller groups in the pons. An exact account of the situations of such cells will be found in Dr. Hill's translation of Obersteiner's "Anatomy of the Central Nerrous Organs." These small cells are perbaps the degenerate representatives in man of groups of cells which in the lower animals had a functional importance for which in man there is no demand. If so 
IENTICOLAR, SPINAL AND CARDIAC GANGLIA. 347

their existence supports the view here expressed, that many nervous ganglia are in man degenerate, and in reality represent organs which were active in the lower animals.

The ganglion of the trunk of the vagus has been described by Levin (Lancet, July 14, 1888, p. 78) as containing granular pigmented cells, probably therefore it is in man an atrophied degenerate organ. 